\title{
Faktor Risiko Demam Berdarah di Negara Tropis
}

\section{Risk Factors of Dengue Hemorrhagic Fever in Tropical Countries}

\author{
Zata Ismah $^{1 *}$, Tri Bayu Purnama ${ }^{1}$, Dyah Retno Wulandari ${ }^{1}$, Ema Rizka Sazkiah ${ }^{1}$, Yulia Khairina Ashar ${ }^{1}$ \\ ${ }^{1}$ Fakultas Kesehatan Masyarakat, Universitas Islam Negeri Sumatera Utara Medan, Jl. IAIN No. 1, Medan, 20154, Indonesia
}

Kutipan: Ismah Z, Purnama TB, Wulandari DR, Sazkiah ER, Ashar

YK. Faktor Risiko Demam Berdarah di Negara Tropis. ASP. Desember 2021: 13(2): $147-158$

Editor: Rohmansyah Wahyu Nurindra Diterima: 08 Maret 2021

Revisi: 06 Mei 2021

Layak Terbit: 06 Desember 2021

Catatan Penerbit: Aspirator tetap netral dalam hal klaim yurisdiksi di peta yang diterbitkan dan afiliasi kelembagaan.

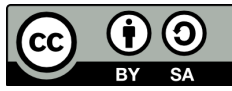

Hak Cipta: (C) 2021 oleh penulis. Pemegang lisensi Loka Litbangkes Pangandaran, Indonesia. Artikel ini adalah artikel dengan akses terbuka yang didistribusikan dengan syarat dan ketentuan lisensi Creative Commons Attribution Share-Alike (CC BY SA) (https://creativecommons.org/ licenses/by-sa/2.0/)

*Korespondensi Penulis

Email: zataismah@gmail.com

\begin{abstract}
Tropical countries are the largest contributor to the incidence of Dengue Hemorrhagic Fever (DHF), but research on risk factors is still independent in various countries, it cannot be concluded holistically. Through the research design, a systematic review is able to summarize and answer the causes of DHF in this tropical country. This research method is a systematic review with guidelines following the 2009 PRISMA Checklist. In the initial search, 1,680 articles were found using the keyword "risk factors for Dengue Hemorrhagic Fever", reduced to 274 article titles after adding the keyword "tropical country". Furthermore, the relevant abstracts were filtered and found 37 selected article items. Through critical appraisal of the full text of the article, it was found that 17 articles met the selection criteria for further review in this study. The results showed that there were 5 major groups of risk factors that were widely studied, namely sociodemography, climatology, place of dwelling, environment, and behavior. The sociodemographic factor associated with the incidence of DHF in tropical countries is age. In terms of climatology, temperature and rainfall are important factors in the vector breeding process. Rural areas (rural areas) are the place of dwelling with the most cases of DHF found. The environmental aspect that has been widely studied is mosquito breeding. The most significant risk behavior factor in transmission was the behavior of hanging clothes. Of the 17 articles, it was found that $77.8 \%$ of the articles examined environmental variables.
\end{abstract}

Keywords: risk factor, DHF, tropic, systematic review

Abstrak. Negara tropis menjadi penyumbang kasus terbesar terhadap kejadian demam berdarah dengue (DBD), namun penelitian faktor risiko DBD masih independen di berbagai negara, sehingga belum dapat disimpulkan secara holistik. Melalui desain penelitian systematic review mampu merangkum dan menjawab penyebab DBD di negara tropis tersebut. Metode penelitian ini adalah systematic review dengan pedoman mengikuti PRISMA Cheklist tahun 2009. Pada pencarian awal ditemukan sebanyak 1.680 artikel menggunakan kata kunci "faktor risiko Deman Berdarah Dengue", berkurang menjadi 274 judul artikel setelah penambahan kata kunci "tropical country". Selanjutnya disaring abstrak yang relevan dan ditemukan 37 item artikel terpilih. Melalui critical aprasial teks artikel lengkap, didapatkan 17 artikel memenuhi kriteria seleksi untuk selanjutnya di-review dalam penelitian ini. Hasil penelitian didapatkan 5 kelompok besar faktor risiko yang banyak diteliti yaitu sosiodemografi, geografi, place of dwelling, lingkungan dan perilaku. Faktor sosiodemografi yang berhubungan dengan kejadian DBD di negara tropis adalah usia. Pada faktor klimatologi, suhu dan curah hujan yang merupakan faktor penting dalam proses perkembangbiakan vektor. Daerah rural (perdesaan) merupakan place of dwelling yang paling banyak ditemukan kasus DBD. Aspek lingkungan yang banyak diteliti adalah perindukan nyamuk. Faktor perilaku yang berisiko dalam penularan yang paling banyak ditemukan signifikan yaitu perilaku menggantung pakaian. Dari 17 artikel, ditemukan 77,8\% artikel semuanya meneliti variabel lingkungan.

Kata Kunci: faktor risiko, DBD, tropis, systematic review 


\section{PENDAHULUAN}

Demam Berdarah Dengue (DBD) termasuk jenis penyakit arbovirus yang ditularkan oleh dua jenis vektor nyamuk yaitu Aedes aegypti dan Aedes Albopictus dan merupakan masalah utama penyakit di dunia, terutama di negara tropis. Sampai tahun 2009, sekitar 2-5 miliar orang yang tinggal di lebih 100 negara endemik, terutama daerah tropis yang rentan penularan virus dengue. Data dari World Health Organization (WHO) tahun 2015 menyatakan negara tropis berisiko terinfeksi virus dengue dengan 96 juta kasus berasal dari 128 negara tropis. Angka tersebut menjadikan negara tropis penyumbang kasus terbesar kejadian DBD. Pada 2016 lebih dari 136 kasus DBD di Thailand,176.411 kasus terlaporkan di Filipina dan sebanyak 100.028 kasus di Malaysia. Di Asia Tenggara terjadi kematian rata-rata 1682 jiwa/tahun karena DBD. Pada peringatan ASEAN Dengue Day (ADD) tahun 2016 WHO juga melaporkan bahwa Asia Pasifik menanggung 75\% dari beban dengue di dunia antara tahun 2004 dan 2010. Tahun 2019, Kepulauan Solomon melaporkan wabah Demam Berdarah Dengue (DBD) terdapat lebih dari 7.000 kasus dan wabah wilayah Afrika, Burkina Faso 1.061 kasus yang dilaporkan. ${ }^{1}$

Hasil penelitian Fahrizal (2018) menyebutkan bahwa negara tropis memiliki tingkat curah hujan, kelembapan, suhu, dan urbanisasi yang teridentifikasi sebagai faktor risiko wabah penyakit demam berdarah. ${ }^{2}$ Transmisi persebaran virus dapat disebabkan oleh berbagai faktor, salah satunya adalah kepadatan vektor nyamuk. Kondisi alam suatu wilayah berkontribusi terhadap angka kejadian DBD , seperti ketinggian tempat yang berkolerasi dengan kelembapan sehingga mempengaruhi kepadatan jentik vektor. ${ }^{3}$ Peningkatan demam berdarah juga dipengaruhi oleh perubahan iklim di daerah tropis yang diekspresikan dengan meningkatnya pemanasan suhu. Hal ini terbukti dalam penelitian Lalusu (2017) yang menyebutkan bahwa peningkatan suhu dan sinar matahari pada tiga bulan sebelumnya berkorelasi dengan peningkatan DBD pada bulan berikutnya. ${ }^{4}$

Perubahan iklim memengaruhi 2 kejadian utama dalam rantai penularan. Pertama peningkatan patogenesitas vektor dan kedua memengaruhi host menjadi rentan. Faktor pertama, perubahan iklim memengaruhi perilaku dan evaporasi vektor, dan laju perkembangan patogen dalam vektor sehingga masa inkubasi ekstrinsik menjadi lebih singkat. ${ }^{5}$ Suhu yang meningkat membuat vektor berukuran lebih kecil sehingga pergerakannya lebih agresif. ${ }^{6}$ Faktor kedua, perubahan iklim membuat host harus beradaptasi dengan cepat sehingga meyebabkan turunnya daya imunitas terutama pada golongan bayi dan anak-anak. Pada suhu lingkungan semakin panas tubuh host akan sulit mempertahankan suhu tubuhnya sehingga agen dapat beradaptasi mendekati suhu host. Imunitas host yang terpapar panas tidak kompetitif dalam menghadapi agent. $^{7}$

Penelitian faktor risiko DBD masih independen di berbagai negara, sehingga faktor risiko DBD di negara tropis belum dapat disimpulkan secara holistik. Padahal DBD sangat erat dengan kondisi iklim dan geografis. Melalui desain penelitian Systematic review, mampu merangkum dan menjawab penyebab DBD di negara tropis tersebut. Review secara sistematis digunakan untuk menemukan sejauh mana riset yang telah dilakukan, menemukan structure overview, metode yang digunakan dan mencari variabel yang relevan terhadap penjelasan faktor risiko demam berdarah. Sejauh ini di berbagai negara tropis belum terdapat penelitian terbaru yang secara khusus meneliti secara komprehensif mengapa negara tropis menjadi endemis Demam Berdarah Dengue (DBD). Oleh sebab itu dilakukan penelitian ini dengan menggunakan Systematic review, untuk mengetahui faktor risiko demam berdarah di negara tropis.

\section{METODE}

Metode penelitian ini adalah systematic review dengan pedoman mengikuti PRISMA Cheklist tahun 2009. Adapun kriteria literatur yang digunakan berupa jurnal ilmiah atau 
prosiding dengan pencarian secara komprehensif dari 4 basis data jurnal terindeks Medline/Pubmed, EMBASE, PsycINFO dan Google Cendekia dimulai dari 21 Oktober 2019 hingga 12 November 2020 dan menemukan 17 artikel yang memenuhi kriteria.

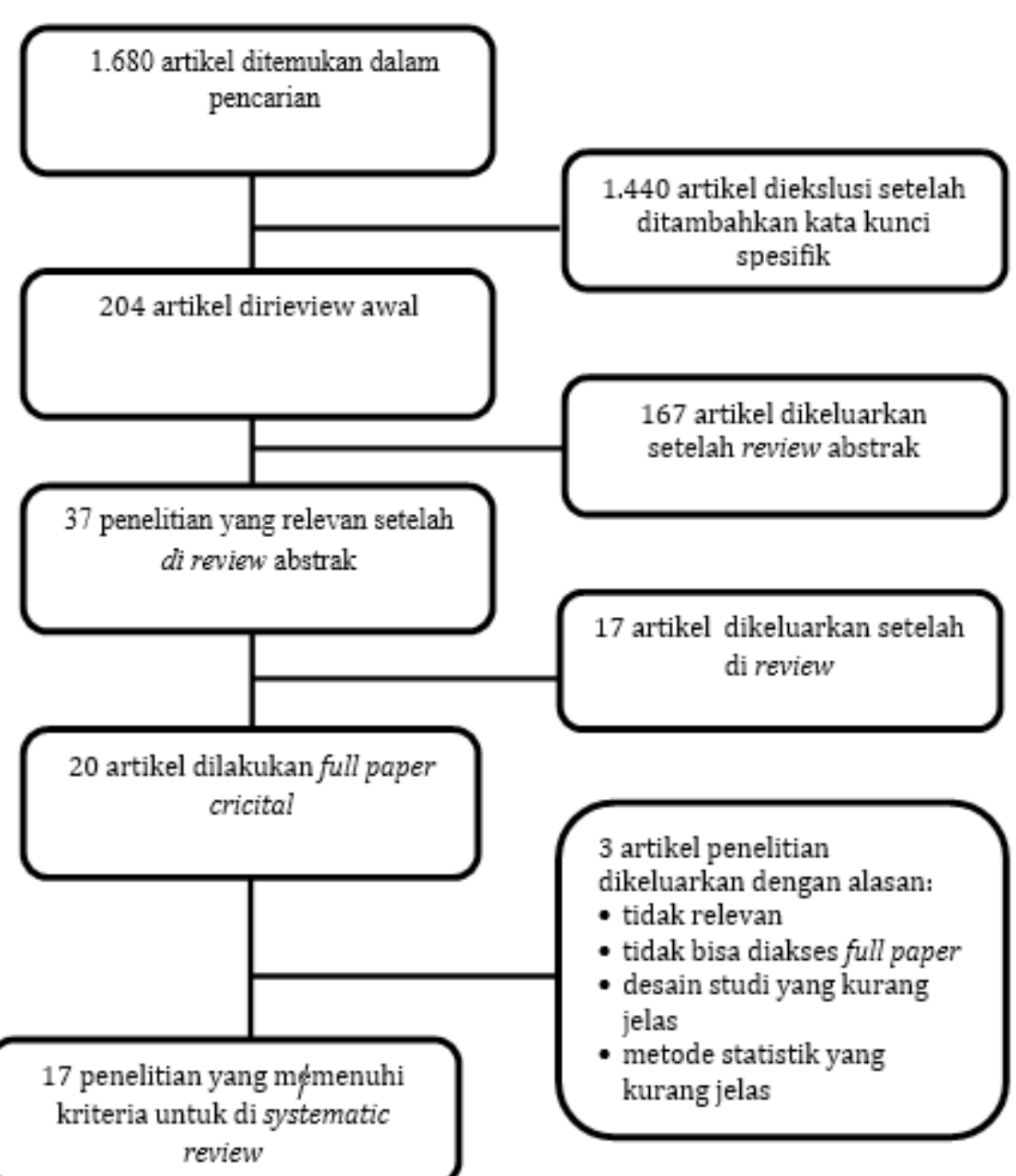

Penelitian termasuk desain studi casecontrol dan cohort tentang DBD di negara Tropis Risiko DBD

Gambar 1. Rincian proses pemilihan artikel

\section{Strategi Pencarian}

Pencarian dilakukan dengan mengidentifikasi artikel yang diterbitkan lima tahun terakhir serta dipublikasi dalam database elektronik seperti Medline/Pubmed, EMBASE, PsycINFO dan Google Cendekia. Pencarian juga dilakukan secara manual untuk studi tambahan yang relevan, dengan melakukan pemindaian dan penapisan terhadap artikel yang didapat tentang topik yang dipilih dan mengeluarkan literatur yang disesuaikan dengan kriteria inklusi dan ekslusi.

Untuk mendapatkan jumlah maksimum kutipan yang relevan, digunakan kata kunci pencarian judul dengan melewati beberapa langkah. Pada langkah I, dilakukan pencarian dengan kalimat "Faktor Risiko Demam Berdarah Dengue (DHF Risk Factor)", ditemukan sebanyak 1.680 judul pada pencarian pertama. Kemudian, pada langkah II, ditambahkan dalam pencarian dengan kata kunci “Negara Tropis (Tropical 
Countries)". Didapatkan sebanyak 204 judul untuk selanjutnya pada langkah III diseleksi berdasarkan kriteria-kriteria dengan melakukan skrining abstrak serta mengacu pada panduan PRISMA Cheklist 2009, didapatkan 17 naskah yang sesuai.

\section{Kriteria Inklusi dan Ekslusi}

Berikut merupakan kriteria inklusi dan ekslusi untuk pemilihan artikel yang digunakan. Bagi kriteria inklusi, yaitu 1) diterbikan antara November 2014 dan November 2020; 2) ditulis dalam Bahasa Indonesia atau Bahasa inggris; 3) desain studi adalah kuantitatif diutamakan Case Control atau Cohort; 4) penelitian mengenai DBD dari berbagai Negara Tropis dan dengan nilai odds ratio (OR) dan relative risk (RR) yang jelas. Adapun kriteria ekslusi, yaitu 1) hasil laporan kasus, buletin, atau review laporan penelitian, dan 2) tidak memberikan informasi yang cukup pada kriteria inklusi.

\section{Pilihan Artikel}

Penulis secara independen menyaring abstrak yang relevan kemudian ditemukan 37 item artikel terpilih. Melalui diskusi dan critical aprasial teks artikel lengkap pada 37 artikel, didapatkan 17 artikel memenuhi kriteria seleksi untuk selanjutnya di-review dalam artikel ini. Alur pencarian artikel dapat dilihat pada Gambar 1.

\section{HASIL}

Penulis menemukan penelitian pada pencarian awal sebesar 1.680 dengan kata kunci "faktor risiko demam berdarah dengue". Kemudian, berkurang drastis menjadi 204 judul artikel setelah menambahkan kata kunci "negara tropis". Selanjutnya dilakukan pemilahan berdasarkan judul, ditemukan 37 judul yang berpotensi dan relevan untuk kemudian dilakukan penapisan dengan membaca abstraknya. Tahap akhir, dilakukan critical appraisal teks lengkap dari 37 judul dan didapatkan 17 judul terpilih sebagai artikel yang layak untuk di-review dalam penelitian ini. Ringkasan variabel penelitian dari penelitian tersebut dapat dilihat pada Tabel 1 dan 2.

Tabel 1. Identitas Jurnal Penelitian yang di-Review

\begin{tabular}{|c|c|c|c|c|c|}
\hline No & $\begin{array}{l}\text { Nama Penulis, } \\
\text { (Tahun Publikasi) }\end{array}$ & Judul Artikel & $n$ & $\begin{array}{c}\text { Desain } \\
\text { Penelitian }\end{array}$ & Lokasi \\
\hline 1. & Debora et al $(2017)^{8}$ & $\begin{array}{l}\text { Analysis of the Risk Factors of Dengue } \\
\text { Hemorrhagic Fever (DHF) In Rural Populations } \\
\text { in Panongan Subdistrict, Tangerang } 2016\end{array}$ & 190 & Case control & $\begin{array}{l}\text { Panongan } \\
\text { Indonesia }\end{array}$ \\
\hline 2. & $\begin{array}{l}\text { Ayuningtyas dkk } \\
(2019)^{9}\end{array}$ & $\begin{array}{l}\text { Risk Factors of Dengue Fever: Application of } \\
\text { PRECEDE - PROCEED Model }\end{array}$ & 200 & Case control & $\begin{array}{l}\text { Sukoharjo } \\
\text { Indonesia }\end{array}$ \\
\hline 3. & Yung et al (2016) $)^{10}$ & $\begin{array}{l}\text { Epidemiological risk factors for adult dengue in } \\
\text { Singapore: an } 8 \text {-year nested test negative case } \\
\text { control study }\end{array}$ & 3246 & Case control & Singapore \\
\hline 4. & Swain et al (2019) & $\begin{array}{l}\text { Risk factors for dengue outbreaks in Odisha, } \\
\text { India: A case-control study }\end{array}$ & 767 & Case control & $\begin{array}{l}\text { Odisha, } \\
\text { India }\end{array}$ \\
\hline 5. & $\begin{array}{l}\text { Fuadzy dkk } \\
(2020)^{12}\end{array}$ & $\begin{array}{l}\text { Risk factors associated with Dengue incidence } \\
\text { in Bandung, Indonesia: a household based case- } \\
\text { control study }\end{array}$ & 781 & Case control & $\begin{array}{l}\text { Bandung, } \\
\text { Indonesia }\end{array}$ \\
\hline 6. & $\begin{array}{l}\text { Fitriana dkk } \\
(2018)^{13}\end{array}$ & $\begin{array}{l}\text { Hubungan Faktor Suhu Dengan Kasus Demam } \\
\text { Berdarah Dengue (DBD) Di Kecamatan } \\
\text { Sawahan Surabaya }\end{array}$ & 112 & Case control & $\begin{array}{l}\text { Surabaya } \\
\text { Indonesia }\end{array}$ \\
\hline 7. & $\begin{array}{l}\text { Marwanthy dkk } \\
(2018)^{14}\end{array}$ & $\begin{array}{l}\text { Faktor Lingkungan Rumah dan Kejadian } \\
\text { Demam Berdarah Dengue di } \\
\text { Kota Palopo } 2016\end{array}$ & 236 & Case control & $\begin{array}{l}\text { Palopo } \\
\text { Indonesia }\end{array}$ \\
\hline 8. & Iriani dkk (2019) ${ }^{15}$ & $\begin{array}{l}\text { Hubungan antara Curah Hujan dan } \\
\text { Peningkatan Kasus Demam Berdarah Dengue } \\
\text { Anak di Kota Palembang }\end{array}$ & $\begin{array}{l}\text { Semua kasus di } 3 \\
\text { rumah sakit }\end{array}$ & Ekologi & $\begin{array}{l}\text { Palembang } \\
\text { Indonesia }\end{array}$ \\
\hline 9. & $\begin{array}{l}\text { Nguyen-Tien et al } \\
(2020)^{16}\end{array}$ & $\begin{array}{l}\text { Risk factors of dengue fever in an urban area in } \\
\text { Vietnam: a case-control study }\end{array}$ & 197 & Case control & $\begin{array}{l}\text { Hanoi } \\
\text { Vietnam }\end{array}$ \\
\hline 10. & $\begin{array}{l}\text { Sitepu dkk } \\
(2019)^{17}\end{array}$ & $\begin{array}{l}\text { Risk Factors of Dengue Fever Outbreak in Karo } \\
\text { District, North Sumatera, Indonesia }\end{array}$ & 74 & Case control & $\begin{array}{l}\text { Karo } \\
\text { Indonesia }\end{array}$ \\
\hline 11. & $\begin{array}{l}\text { Hasanah dkk } \\
(2019)^{18}\end{array}$ & $\begin{array}{l}\text { Weather Implication for Dengue Fever in } \\
\text { Jakarta, Indonesia 2008-2016 }\end{array}$ & $\begin{array}{l}\text { Semua kasus DKI } \\
\text { Jakarta }\end{array}$ & Ekologi & $\begin{array}{l}\text { DKI Jakarta } \\
\text { Indonesia }\end{array}$ \\
\hline
\end{tabular}



12. Mai et al
$(2018)^{19}$
13. Liew et al $(2016)^{20}$
14. Wakimoto et al $(2017)^{21}$
15. Liu et al
$(2019)^{22}$
16. Sinaga dkk $(2019)^{23}$
17. Respati dkk $(2017)^{24}$ in Khanh Hoa Province, Viet Nam: A Stratified Cluster Sampling Survey

757,345, (Nha

Trang) 367,484 , Ninh Hoa 241,173

Dien Khanh

$\begin{array}{rll}43347 & \text { Cohort } & \text { Malaysia } \\ 233 & \text { Case control } & \text { Brazil } \\ 474 & \text { Case control } & \begin{array}{l}\text { Guangdong } \\ \text { China }\end{array} \\ 40 & \text { Case control } & \begin{array}{l}\text { Medan } \\ \text { Indonesia }\end{array} \\ 2035 & \text { Crosssectional } & \begin{array}{l}\text { Bandung } \\ \text { Indonesia }\end{array}\end{array}$

Tabel 2. Ringkasan Variabel Penelitian dalam Systematic Review

\begin{tabular}{|c|c|c|c|c|c|c|c|c|c|c|c|c|c|c|c|c|c|}
\hline Kriteria Penilaian Kualitas & 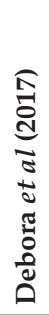 & 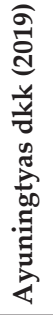 & 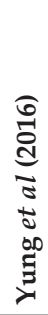 & 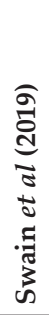 & 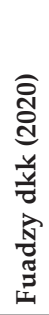 & 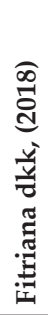 & 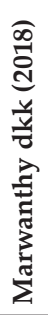 & 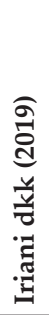 & 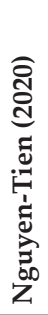 & 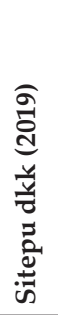 & 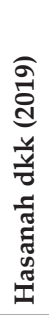 & 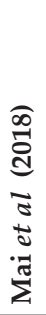 & 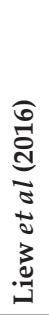 & 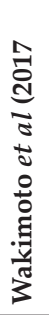 & 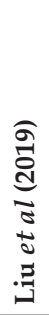 & 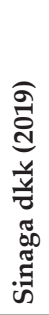 & 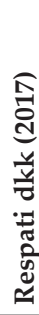 \\
\hline Umur & $\sqrt{ }$ & $\sqrt{ }$ & $\sqrt{ }$ & $\sqrt{ }$ & $\sqrt{ }$ & & $\sqrt{ }$ & & $\sqrt{ }$ & & & & $\sqrt{ }$ & $\sqrt{ }$ & & & \\
\hline Jenis kelamin & $\sqrt{ }$ & $\sqrt{ }$ & $\sqrt{ }$ & $\sqrt{ }$ & & & $\sqrt{ }$ & & $\sqrt{ }$ & & & & $\sqrt{ }$ & $\sqrt{ }$ & & & $\sqrt{ }$ \\
\hline Pendidikan & $\sqrt{ }$ & $\sqrt{ }$ & & $\sqrt{ }$ & $\sqrt{ }$ & & $\sqrt{ }$ & & $\sqrt{ }$ & & & $\sqrt{ }$ & & & & & $\sqrt{ }$ \\
\hline Pekerjaan & $\sqrt{ }$ & & & & & & $\sqrt{ }$ & & $\sqrt{ }$ & & & $\sqrt{ }$ & & & & & \\
\hline Status pernikahan & & & & & & & & & $\sqrt{ }$ & & & & & & $\sqrt{ }$ & & \\
\hline Etnis & & & $\sqrt{ }$ & $\sqrt{ }$ & & & & & & & & & & $\sqrt{ }$ & & & \\
\hline Mobilitas & $\sqrt{ }$ & & $\sqrt{ }$ & $\sqrt{ }$ & & & $\sqrt{ }$ & & & $\sqrt{ }$ & & $\sqrt{ }$ & & & $\sqrt{ }$ & & \\
\hline Curah hujan & & & & & & $\sqrt{ }$ & & $\sqrt{ }$ & & & $\sqrt{ }$ & & & & & & \\
\hline Suhu & & & & & & $\sqrt{ }$ & & & & & $\sqrt{ }$ & & & & & & \\
\hline Kelembapan & & & & & & $\sqrt{ }$ & & & & & $\sqrt{ }$ & & & & & & \\
\hline Urban & & & & $\sqrt{ }$ & & & & & $\sqrt{ }$ & & & $\sqrt{ }$ & $\sqrt{ }$ & & $\sqrt{ }$ & & \\
\hline Rural & $\sqrt{ }$ & & & & & & & & & & & & & & $\sqrt{ }$ & & $\sqrt{ }$ \\
\hline Ventilasi rumah & & & & & $\sqrt{ }$ & & $\sqrt{ }$ & & & & & & & & & & \\
\hline Sanitasi & $\sqrt{ }$ & & & & $\sqrt{ }$ & & $\sqrt{ }$ & & $\sqrt{ }$ & & & & & & & & \\
\hline Tipe rumah & $\sqrt{ }$ & & & & $\sqrt{ }$ & & $\sqrt{ }$ & & $\sqrt{ }$ & & & & & & & & \\
\hline Jumlah penghuni rumah & & & & & & & $\sqrt{ }$ & & & & & & & & $\sqrt{ }$ & & \\
\hline Keluarga riwayat DBD & & & & & $\sqrt{ }$ & & $\sqrt{ }$ & & & $\sqrt{ }$ & & & $\sqrt{ }$ & & & & \\
\hline Kontak dengan penderita & & & & & & & & & & & & & $\sqrt{ }$ & & & & \\
\hline Penggunaan pendingin ruangan & & & & & & & & & & & & & & & $\sqrt{ }$ & & \\
\hline Pencahayaan ruangan & & & & & & & & & & & & & & & $\sqrt{ }$ & & \\
\hline Perkembangbiakan nyamuk & & & & $\sqrt{ }$ & & & & & & $\sqrt{ }$ & & $\sqrt{ }$ & & & & $\sqrt{ }$ & \\
\hline \multicolumn{18}{|l|}{ Perilaku pencegahan } \\
\hline Penggunaan anti nyamuk & & $\sqrt{ }$ & & & $\sqrt{ }$ & & & & & $\sqrt{ }$ & & & & & & $\sqrt{ }$ & $\sqrt{ }$ \\
\hline Menggantung pakaian & & & & & & & $\sqrt{ }$ & & & $\sqrt{ }$ & & & & & & $\sqrt{ }$ & \\
\hline Pakaian yang digunakan & & & & & & & & & & & & $\sqrt{ }$ & $\sqrt{ }$ & & & & \\
\hline Pemanfaatan pelayanan kesehatan & & & & & $\sqrt{ }$ & & & & & & & $\sqrt{ }$ & & & & & \\
\hline $\begin{array}{l}\text { Pemanfaatan long lasting insecticidal } \\
\text { nets }\end{array}$ & $\sqrt{ }$ & & & & & & & & & $\sqrt{ }$ & & & & & & & \\
\hline
\end{tabular}


Pada Tabel 1 dan 2 terlihat, dari 17 artikel, 12 artikel menggunakan desain case control dan selebihnya menggunakan desain penelitian crossectional dan ekologi (korelasional) yang difokuskan terhadap faktor-faktor yang memengaruhi DBD. Dari tabel terlihat bahwa variabel yang berkaitan dengan lingkungan merupakan variabel yang banyak diteliti.

Tabel 3. Perbandingan Data Artikel Faktor Resiko DBD di Negara Tropis

\begin{tabular}{|c|c|c|c|c|c|c|c|c|}
\hline \multirow{3}{*}{ Variabel } & \multirow{3}{*}{ Faktor Risiko } & \multicolumn{5}{|c|}{ Hasil Penelitian } & \multirow{2}{*}{\multicolumn{2}{|c|}{ Total }} \\
\hline & & \multicolumn{2}{|c|}{ Signifikan } & \multirow{2}{*}{ OR } & \multicolumn{2}{|c|}{ Tidak Signifikan } & & \\
\hline & & $\mathrm{n}$ & $\%$ & & $\mathbf{n}$ & $\%$ & $\mathrm{n}$ & $\%$ \\
\hline \multirow{7}{*}{ Sosiodemografi } & Umur & 4 & 44.4 & $1.04,9.0,2.53,0.311$ & 5 & 55.6 & 9 & 100 \\
\hline & Jenis kelamin & 2 & 22.2 & $4.99,5.6$ & 7 & 77.8 & 9 & 100 \\
\hline & Pendidikan & 4 & 50 & $1.4,2.21,2.7,2,48$ & 4 & 50 & 8 & 100 \\
\hline & Status pernikahan & 1 & 50 & 2,48 & 1 & 50 & 2 & 100 \\
\hline & Pekerjaan & 2 & 50 & $3.7,2,77$ & 2 & 50 & 4 & 100 \\
\hline & Etnis & 0 & 0 & 0 & 3 & 100 & 3 & 100 \\
\hline & Mobilitas & 3 & 42.9 & $2.28,1.6,1.74$ & 4 & 57.1 & 7 & 100 \\
\hline \multirow{3}{*}{ Klimatologi } & Curah hujan & 2 & 66.7 & $<0.005,0.018$ & 1 & 33.3 & 3 & 100 \\
\hline & Suhu & 2 & 100 & $0.019,<0.005$ & 0 & 0 & 2 & 100 \\
\hline & Kelembapan & 1 & 50 & $<0.005$ & 1 & 50 & 2 & 100 \\
\hline \multirow{2}{*}{ Place Of Dwelling } & Urban & 2 & 40 & $4.6,3,09$ & 3 & 60 & 5 & 100 \\
\hline & Rural & 2 & 66.7 & $1.7,0,597$ & 1 & 33.3 & 3 & 100 \\
\hline \multirow{10}{*}{ Lingkungan } & Ventilasi rumah & 0 & 0 & 0 & 2 & 100 & 2 & 100 \\
\hline & Sanitasi & 3 & 75 & $1.32,4.3,0,68$ & 1 & 25 & 4 & 100 \\
\hline & Dekat genangan air & 2 & 66.7 & $1.5,3.4$ & 1 & 33.3 & 3 & 100 \\
\hline & Tipe rumah & 3 & 75 & $3.25,2.9,2.2,1,7$ & 1 & 25 & 4 & 100 \\
\hline & Jumlah penghuni rumah & 1 & 100 & 0.50 & 0 & 0 & 1 & 100 \\
\hline & Keluarga dengan riwayat DBD & 1 & 25 & 5.18 & 3 & 75 & 4 & 100 \\
\hline & Kontak dengan penderita & 0 & 0 & 0 & 1 & 100 & 1 & 100 \\
\hline & Penggunaan pendingin ruangan & 1 & 100 & 0.4 & 0 & 0 & 1 & 100 \\
\hline & Pencahayaan ruangan & 1 & 100 & 2.32 & 0 & 0 & 1 & 100 \\
\hline & $\begin{array}{l}\text { Keberadan perkembangbiakan } \\
\text { nyamuk/ larva nyamuk }\end{array}$ & 3 & 75 & $4.87,2.68,2,90$ & 1 & 25 & 4 & 100 \\
\hline \multirow{5}{*}{$\begin{array}{l}\text { Perilaku } \\
\text { pencegahan }\end{array}$} & Penggunaan anti nyamuk & 2 & 40 & $5.18,6.68$ & 3 & 60 & 5 & 100 \\
\hline & Menggantung pakaian & 2 & 66.7 & $5.12,3,75$ & 1 & 33.3 & 3 & 100 \\
\hline & Pakain yang digunakan & 0 & 0 & 0 & 2 & 100 & 2 & 100 \\
\hline & Pemanfaatan pelayanan kesehatan & 1 & 50 & 2.9 & 1 & 50 & 2 & 100 \\
\hline & $\begin{array}{l}\text { Pemanfaatan Long Lasting } \\
\text { Insecticidal Nets (LLINs) }\end{array}$ & 0 & 0 & 0 & 2 & 100 & 2 & 100 \\
\hline
\end{tabular}

Pada tabel 3, variabel signifikan dan tidak signifikan dikelompokkan menjadi 5 kelompok besar: 1) Karakteristik responden dikelompokkan menjadi Sosiodemografi; 2) Klimatologi untuk keadaan cuaca; 3) Place of Dwelling untuk wilayah tempat tinggal; 4) Lingkungan untuk keadaan di sekitar tempat tinggal; 5) Perilaku pencegahan untuk tindakan yang dilakukan responden dalam upaya pencegahan. Pengelompokan dilakukan untuk melihat perbandingan data faktor risiko DBD yang paling signifikan di negara tropis.

Variabel yang banyak diteliti dan sekaligus paling banyak signifikansi dengan kejadian DBD adalah umur, curah hujan, suhu, tipe rumah dan keberadan perkembangbiakan nyamuk/ larva nyamuk, perilaku pencegahan, dan perilaku menggantung pakaian. Sedangkan faktor risiko yang ditemukan 100\% tidak signifikan pada beberapa penelitian adalah etnis, pakaian yang digunakan, dan pemanfaatan Long Lasting Insecticidal Nets.

\section{PEMBAHASAN}

Pada studi ini ditemukan faktor risiko demam berdarah dengue di wilayah tropis dengan persentase variabel yang signifikan, yaitu Sosiodemografi (33,5\%), Klimatologi 
(72,2\%), Place Of Dwelling (75\%) , Lingkungan (77,8\%), dan Perilaku Pencegahan (42,8\%). Dalam systematic review ini, penulis secara konsisten mengidentifikasikan faktor resiko dengan persentasi tertinggi dan paling banyak diteliti yaitu lingkungan ( $\mathrm{n}=17,77,8 \%)$.

\section{Sosiodemografi}

Sosiodemografi mengambarkan hubungan yang ada pada masing-masing individu atau kelompok. Sosiodemografi merupakan salah satu komponen yang mengkaji tentang penduduk (satu wilayah) terutama mengenai jumlah, struktur (komposisi penduduk) dan perkembangannya atau perubahannya. Sosiodemografi membahas persebaran, teritorial, dan komposisi penduduk serta perubahan-perubahan yang biasanya timbul karena natalitas (fertilitas), mortalitas, gerak teritorial (migrasi) dan mobilitas sosial (perubahan status). ${ }^{25}$

Dalam systematic review ini, penulis mengidentifikasikan faktor risiko dari demam berdarah, terutama di wilayah tropis salah satunya adalah sosiodemografis yang terdiri dari usia dengan $(n=4) 44 \%$, jenis kelamin $(n=2) 22.2 \%$, pendidikan $(n=4) 50 \%$, status pernikahan $(n=1) 50 \%$, pekerjaan $(n=2) 50 \%$, etnis $(n=0) 0 \%$, dan mobilitas $(n=3) 42.9 \%$. Adapun faktor risiko yang paling banyak diteliti yaitu umur dengan 9 artikel, namun 4 diantaranya menyebutkan signifikan (44\%) dan 5 tidak signifikan (55,6\%).

Sosiodemografi menjadi faktor risiko dalam kejadian DBD, hal ini disebabkan sosiodemografi tidak terlepas dari gambaran masing-masing dari individu atau kelompok. Keterkaitan negara tropis umumnya terdiri dari negara-negara yang masih berkembang dan miskin. Piramida atau komposisi penduduk dari negara-negara berkembang berbentuk piramida ekspansif atau piramida penduduk muda. Salah satunya memiliki penduduk pada usia muda merupakan kelompok terbanyak. Usia merupakan bagian dari sosiodemografi yang paling berpengaruh terhadap kejadian DBD di negara tropis. Sebagaimana diketahui bahwa golongan penduduk usia muda merupakan kelompok rentan terkena DBD. Ditambah lagi negara tropis merupakan negara yang cenderung padat penduduk sehingga menjadi rentan untuk terjadi wabah DBD. ${ }^{26}$ Dalam penelitian Suryani (2018) didapatkan dari analisis data 3 tahunan, bahwa kelompok umur 5-14 tahun adalah kelompok paling banyak terkena demam berdarah. ${ }^{27}$ Golongan umur kurang dari dari 15 tahun mempunyai peluang lebih besar untuk terjangkit DBD. Menurut penelitian Sanra (2019) anak-anak yang rentan DBD selain imunitas lebih rendah juga dikarenakan lebih dikarenakan pola asuh dari ibu, mereka kurang terbiasa dalam penggunaan repellent, dan terbiasa tidak menggunakan baju panjang. ${ }^{28}$

\section{Klimatologi}

Dalam systematic review ini, penulis juga mengidentifikasikan beberapa artikel yang mengungkap aspek klimatologis sebagai faktor risiko dari demam berdarah, yaitu curah hujan $(n=2) 66,7 \%$, suhu $(n=2) 100 \%$ dan kelembapan $(n=1) 50 \%$ merupakan variabel signifikan. Suhu optimum untuk nyamuk berada pada rentang $25^{\circ} \mathrm{C}-27^{\circ} \mathrm{C}$. Selain itu pada rentang suhu $20^{\circ} \mathrm{C}-30^{\circ} \mathrm{C}$ merupakan suhu ideal untuk kelangsungan hidup nyamuk pada semua tahapan siklusnya. ${ }^{18}$

Adapun faktor risiko klimatologi yang paling banyak diteliti yaitu curah hujan dengan 3 artikel 2 diantaranya menyebutkan signifikan (66.7\%) dan 1 tidak signifikan (33.3\%). Penelitian terbaru oleh Triwahyuni pada 2020 menyebutkan bahwa terdapat hubungan bermakna antara curah hujan dengan kasus demam berdarah dengue $(\mathrm{p}=0,006) .{ }^{29}$ Jumlah kasus demam berdarah dengue akan meningkat bila curah hujan meningkat.

Faktor risiko suhu menunjukan nilai signifikan 100\% (n=2) dan kelembaban 50\% $(\mathrm{n}=2)$. Daerah tropis merupakan wilayah yang terletak pada garis-garis khayal, yaitu garis lintang $23,5^{\circ}$ derajat Lintang Utara dan Selatan yang berarti terletak diantara garis 
isotherm $20^{\circ} \mathrm{C}$ di belahan bumi Utara dan Selatan. Suhu rata-rata iklim tropis tahunan diatas $18^{\circ} \mathrm{C}$ dan akan mencapai $38^{\circ} \mathrm{C}$ pada musim kemarau. ${ }^{21}$ Masa inkubasi ekstrinsik virus dalam tubuh nyamuk berkurang dari 9 hari pada suhu $26^{\circ} \mathrm{C}$ dan $28{ }^{\circ} \mathrm{C}$ menjadi 5 hari pada suhu $30^{\circ} \mathrm{C}$. Siklus resproduksi nyamuk betina juga dipegaruhi oleh suhu lingkungan yang mana pada suhu kurang dari $20^{\circ} \mathrm{C}$ fertilisasi nyamuk betina berkurang. Aktivitas menggigit nyamuk betina juga dipengaruhi oleh suhu lingkungan. Aktivitas menggigit nyamuk betina yang tinggi akan meningkatkan penyebaran penyakit DBD. ${ }^{18}$

Perubahan iklim menjadi tantangan bagi global bukan hanya negara tropis. Berdasarkan hasil penelitian Tarmana pada 2017, bahwa akan terjadi penambahan suhu temperatur udara DKI Jakarta hingga tahun 2038 sekitar 0,03 satuan per tahun. Dengan perubahan iklim yang ditandai dengan peningkatan suhu ini menjadikan kota DKI Jakarta akan tetap menjadi daerah dengan risiko tinggi DBD. ${ }^{31}$ Jangkauan geografis dari vektor Aedes aegypti dipengaruhi dan dibatasi oleh suhu lingkungan yang lebih dingin. Saat Bumi menghangat, maka nyamuk dan virus akan menyebar ke lintang dan ketinggian yang lebih tinggi. Hal ini akan meningkatkan insiden penyakit, dan musim penularan akan semakin panjang di beberapa daerah endemik. Pada Aedes albopictus, dan vektor demam berdarah lainnya, telah menunjukkan ekspansi luas ke daerah beriklim sedang akibat perubahan iklim. ${ }^{5}$

Artikel yang mendalami epidemiologi perubahan pola demam berdarah di negara tropis secara longterm akibat perubahan iklim masih sangat sedikit. Walaupun judul artikelnya mengenai perubahan iklim dengan demam berdarah, namun kebanyakan penulis hanya mengambil tren penelitian berkisar 3 tahun. Artikel hanya sekedar membahas korelasi iklim dengan demam berdarah dalam satu waktu saja. Dengan demikian diharapkan artikel selanjutnya dapat mendalami lebih lanjut perubahan iklim ini terhadap epidemiologi pola demam berdarah.

Dapat diambil kesimpulan bahwa faktor klimatologi yang paling berpengaruh terhadap kejadian DBD di negara tropis, yaitu curah hujan dan suhu. Curah hujan memengaruhi keadaan suhu serta kelembapan udara. Suhu dan kelembapan yang optimal akan membantu perkembangbiakan vektor dengue. Pernyataan tersebut sejalan dengan penelitian sebelumnya, yaitu jika curah hujan rendah dengan kurun waktu yang lama yang membuat lingkungan tergenang dapat menambah tempat perindukan nyamuk dan meningkatkan populasi nyamuk. ${ }^{32}$

\section{Place of Dwelling dan Lingkungan}

Aspek Place of Dwelling yang merupakan faktor risiko dari kejadian DBD yang terdiri dari urban (perkotaan) dan rural (pedesaan). Dalam systematic review ini penulis mengidentifikasi faktor risiko DBD di negara tropis dengan memperhitungkan aspek Place of Dwelling dengan total penelitian signifikan $(\mathrm{n}=2)$ sebesar $40 \%$ untuk urban, dan $(n=2)$ sebesar $66.7 \%$ untuk rural. Selanjutnya aspek lingkungan yang paling banyak diteliti dan banyak ditemukan signifikan sebagai faktor risiko dari DBD dalam aspek ini adalah tipe rumah $(n=3) 75 \%$ dan keberadaan tempat perkembanganbiakan nyamuk/ larva nyamuk $(\mathrm{n}=4) 75 \%$.

Pada systematic review ini di dapatkan bahwa rural menjadi tempat paling banyak ditemukan keberadaan nyamuk penyebab demam berdarah dengue. Faktor Place of Dwelling yang paling berpengaruh terhadap kejadian DBD di negara tropis, yaitu rural. Negara beriklim tropis yang didominasi oleh negara berkembang masih memiliki banyak lingkungan pedesaan yang masih terdapat tumbuh-tumbuhan dengan tingkat kerapatan yang tinggi, perkebunan atau tumbuhan liar (semak-semak) hal ini cenderung menjadi tempat perkembangbiakan dari Aedes aegypti.

Pada penelitian oleh Yuliawati pada 2020 di dapatkan hasil bahwa Aedes aegypti dan Ae. albopictus merupakan vektor DBD didaerah rural. Aedes aegypti merupakan 
jenis vektor lebih sering ditemukan di dalam dan sekitar rumah dibandingkan dengan Ae. albopictus serta erat hubungannya dengan manusia. Hal ini dikarenakan pada saat penelitiannya tidak ditemukan tempat bertelur alami Aedes aegypti di luar rumah. Sementara itu penyebaran Ae. albopictus lebih banyak ditemukan habitat perindukan yang cenderung berada di luar rumah, di kebun atau semak-semak dimana terdapat tumbuh-tumbuhannya yang rapat. Dengan demikian daerah rural memiliki risiko penularan baik di dalam rumah maupun di luar rumah. ${ }^{33}$

Aspek lingkungan yang menjadi faktor risiko DBD yang banyak diteliti adalah breeding place atau tempat perindukan nyamuk $(n=4) 75 \%$, seperti genangan air. Populasi nyamuk akan bertambah jika masyarakat menyimpan air dalam tempat penyimpanan air yang akan menjadi breeding place bagi nyamuk. Penyimpanan air yang semakin banyak, akan berisiko meningkatkan Container Index dan Breteau Index menjadi tinggi. ${ }^{33}$ Perilaku Pencegahan

Perilaku pencegahan penyakit DBD merupakan sebuah kegiatan untuk memutus mata rantai nyamuk. Kegiatan pencegahan tersebut mulai dari mencegah penularan penyakit dari gigitan langsung nyamuk betina dewasa yang mengandung virus dengue, dan memberi penguatan kekebalan tubuh pada manusia, maupun pencegahan berbasis lingkugan berupa pengurangan penyebaran jentik atau nyamuk akibat adanya mobilisasi manusia. Perilaku pencegahan perlu ditegakkan terutama pada saat peralihan musim untuk lebih mendorong masyarakat dalam melakukan pemberantasan sarang nyamuk disekitarnya. ${ }^{34}$

Pada hasil systematic review ini, faktor perilaku pencegahan pada masyarakat di daerah tropis yang diteliti terhadap kejadian DBD, yaitu perilaku pencegahan yang berkaitan kepada kebersihan lingkungan. Dari hasil review penelitian ini didapatkan variabel yang paling banyak disimpulkan signifikan pada artikel terpilih yaitu perilaku menggantung pakaian (n=3) 66,7\%. Pada penelitian Kaeng (2020) Kebiasaan menggantung pakaian di dalam rumah tidak memiliki hubungan terhadap terjadinya kasus $D B D .{ }^{35} \mathrm{Hal}$ ini tidak sejalan dengan penelitian terbaru Rosdawati pada 2021 yang menyebutkan bahwa terdapat hubungan yang bermakna antara variabel kebiasaan menggantung pakaian dengan kejadian DBD. ${ }^{36}$ Pakaian-pakaian bekas pakai yang lembab dan jauh dari sorotan cahaya menjadi tempat pilihan nyamuk untuk beristirahat.

Selain perilaku pencegahan lingkungan, perilaku pencegahan dari individu juga penting. Dalam penelitian ini terdapat 2 variabel pencegahan dari individu yang signifikan, yaitu penggunaan antinyamuk (repellent) dan pemanfaatan pelayanan kesehatan. WHO menyatakan bahwa perilaku menggunakan antinyamuk merupakan sarana perlindungan diri terhadap nyamuk maupun serangga yang umum digunakan. Cara lain untuk menghindari gigitan nyamuk adalah dengan membaluri kulit badan dengan obat antinyamuk. ${ }^{37}$ Dalam hal pemanfaatan pelayanan kesehatan, berkaitan dengan terpaparnya masyarakat dalam pelayanan publik terkait pencegahan DBD oleh Dinas Kesehatan atau Puskesmas setempat. Kegiatan tersebut berupa keterlibatan masyarakat seperti kader jumantik atau kegiatan pelatihan dan penyuluhan tentang DBD. Hal ini dibuktikan dalam penelitian Sukayuni pada 2021, bahwa kader jumantik yang berperan baik dalam menjalankan tugasnya secara signifikan dapat mengurangi kejadian DBD ditempat tinggalnya. ${ }^{38}$

\section{KESIMPULAN}

Dari 17 jurnal yang di-review, 12 artikel dengan desain case control dan selebihnya menggunakan studi ekologi, cohort, dan crossectional. Sebanyak 77,8\% dari 17 artikel penelitian tidak ada yang melewatkan aspek lingkungan dalam penelitiannya. Pada faktor yang memengaruhi kejadian DBD pada daerah tropis ditemukan 5 faktor besar dalam berbagai penelitian, yaitu sosiodemografi, klimatologi, place of dwelling, 
lingkungan, dan perilaku pencegahan. Pada faktor klimatologi, suhu dan curah hujan menjadi variabel yang paling banyak ditemukan signifikan. Pada variabel sosiodemografis variabel yang paling banyak ditemukan signifikan adalah usia. Variabel lainnya adalah place of dwelling dimana daerah rural menjadi daerah yang sering ditemukan kasus DBD. Aspek lingkungan yang banyak diteliti adalah tempat perindukan nyamuk, sedangkan perilaku yang signifikan terhadap kejadian DBD adalah perilaku menggantung pakaian.

\section{UCAPAN TERIMA KASIH}

Penulis mengucapkan terimakasih kepada pimpinan Fakultas Kesehatan Masyarakat Universitas Islam Negeri Sumatera Utara atas dukungan moral dan materil selama pembuatan systematic review ini.

\section{KONTRIBUSI PENULIS}

Peran penulis pada artikel ini, Zata Ismah, Dyah Retno Wulandari, dan Ema Rizka Sazkiah berperan sebagai kontributor utama, sedangkan Tri Bayu Purnama dan Yulia Khairina Ashar sebagai kontributor anggota. Kontribusi setiap penulis dapat dilihat pada rincian berikut:

$\begin{array}{ll}\text { Konsep } & : \text { ZI } \\ \text { Kurasi Data } & : \text { ZI, TBP } \\ \text { Analisis Data; Investigasi; Metodologi } & : \text { ZI; DRW; ERS } \\ \text { Supervisi } & : \text { ZI; TBP; YKA } \\ \text { Visualisasi } & : \text { ZI; YKA } \\ \text { Menulis - Membuat Draft } & : \text { Semua penulis }\end{array}$

\section{DAFTAR RUJUKAN}

1. WHO. Update on the dengue situation in the Western Pacific Region Northern Hemisphere [Internet]. Vol. 2016, Who Western Pasific Region. 2016. Available from: https://iris.wpro.who.int/bitstream/handle/10665.1/14182/Dengue-20160823. pdf

2. Fahrizal, Wardani D, Suroso E, Bakri S. Dampak perubahan iklim dan tingkat urbanisme wilayah terhadap biaya korbanan demam berdarah dengue. Diaspora: Eksakta. 2018;1(2):1-10.

3. Supriyadi Y, Darmiah D, Suryatinah Y. Pola kepadatan populasi vektor penyakit DBD di permukiman penduduk bantaran Sungai Martapura Kecamatan Martapura Timur Tahun 2017. JHECDs J Heal Epidemiol Commun Dis [Internet]. 2019 Jan 28;4(2 SE-Articles). Available from: https://ejournal2.litbang.kemkes.go.id/index. php/jhecds/article/view/370

4. Yusnita Lalusu E, Herawati H, Kodim N. Climate Change And Dengue Hemorrhagic Fever In Banggai Regency. 2018;9(PHICo 2017):148-52.

5. Rocklöv J, Dubrow R. Climate change: an enduring challenge for vector-borne disease prevention and control. Nat Immunol. 2020;21(5):479-83.

6. Susilawati. Dampak Perubahan Iklim Terhadap Kesehatan. e-SEHAD. 2021;1(2):2531.

7. Goudarzi S. How a Warming Climate Could Affect the Spread of Diseases Similar to COVID-19 [Internet]. Scientific American. 2020. Available from: https://www. scientificamerican.com/article/how-a-warming-climate-could-affect-the-spread-ofdiseases-similar-to-covid-19/

8. Debora S, Djadja IM, Ririn A. Analysis Of The Risk Factors Of Dengue Hemorrhagic Fever (Dhf) In Rural Populations In Panongan Subdistrict, Tangerang 2016. Knowl E Life Sci (ICGH Conf Proceeding). 2017;8:199-128. 
9. Ayuningtyas KD, Rahardjo S, Sri MB. Risk Factors Of Dengue Fever: Application Of Precede- Proceed Model. J Epidemiol Public Heal. 2019;4(1):37-46.

10. Yung CF, Chan SP, Thein TL, Chai SC, Leo YS. Epidemiological risk factors for adult dengue in Singapore: an 8-year nested test negative case control study. BMC Infect Dis. 2016;16:232.

11. Swain S, Bhatt M, Biswal D, Pati S, Magalhaes R. Risk Factors For Dengue Outbreaks In Odisha, India: A Case-Control study. Elsevier J Infect Public Heal. 2019;21:1-7.

12. Fuadzy H, Widawati M, Astuti EP, Prasetyowati H, Hendri J, Nurindra RW, et al. Risk factors associated with Dengue incidence in Bandung, Indonesia: a household based case-control study. Heal Sci J Indones. 2020;11(1):45-51.

13. Fitriana BR. Hubungan Faktor Suhu Dengan Kasus Demam Berdarah Dengue (Dbd) Di Kecamatan Sawahan Surabaya. Indones J Public Heal. 2019;13(1):85.

14. Marwanty M, Miko Wahyono TY. Faktor Lingkungan Rumah dan Kejadian Demam Berdarah Dengue di Kota Palopo 2016. J Epidemiol Kesehat Indones. 2019;2(1):1926.

15. Iriani Y. Hubungan antara Curah Hujan dan Peningkatan Kasus Demam Berdarah Dengue Anak di Kota Palembang. Sari Pediatr. 2016;13(6):378.

16. Nguyen-Tien T, Do DC, Le XL, Dinh TH, Lindeborg M, Nguyen-Viet H, et al. Risk factors of dengue fever in an urban area in Vietnam: a case-control study. 2BMC Public Heal. 2020;21:664.

17. Sitepu F, Depari E, Kemit S. Risk Factors of Dengue Fever Outbreak in Karo District, North Sumatera, Indonesia. JHealth EpidemiolCommunDis. 2019;5(1):16-22.

18. Hasanah, Susanna D. Weather Implication for Dengue Fever in Jakarta, Indonesia 2008-2016. KnE Life Sci [Internet]. 2019;2019:184-92. Available from: https:// knepublishing.com/index.php/KnE-Life/article/view/3719/7707\#citations

19. Mai Q, Mai T, Tam N, Nghia L, Komada K, Murakami H. Prevalence and Risk Factors of Dengue Infection in Khanh Hoa Province, Viet Nam: A Stratified Cluster Sampling Survey. J-Epidemiol. 2018;28(12):488-97.

20. Liew SM, Khoo EM, Ho BK, Lee YK, Omar M, Ayadurai V, et al. Dengue in Malaysia: Factors Associated with Dengue Mortality from a National Registry. PLoS One. 2016;11(6).

21. Wakimoto MD, Camacho LAB, Gonin ML, Brasil P. Clinical and Laboratory Factors Associated with Severe Dengue: A Case-Control Study of Hospitalized Children. J Trop Pediatr. 2018;64(5):373-81.

22. Liu J, Tian X, Deng Y, Du Z, Liang T, Hao Y, et al. Risk Factors Associated with Dengue Virus Infection in Guangdong Province: A Community-Based CaseControl Study. Int J Env Res Public Heal. 2019;16(4):617.

23. Sinaga P, Hartono. Determinants Of Dengue Hemorrhagic Disease (DHF) Events In The Johor Medan HealthCenter. J Kesehat Glob. 2019;2(3):110-21.

24. Respati T, Raksanagara A, Djuhaeni H, Sofyan A, Faridah L, Agustian D. Berbagai Faktor yang Memengaruhi Kejadian Demam Berdarah Dengue di Kota Bandung. J Aspirator. 2017;9(2):91-6.

25. Abdullah KB. Socio-Demographic Status: Theory, Methods and Applications [Internet]. Preprints. 2019. Available from: www.preprints.org

26. Hsu JC, Hsieh CL, Lu CY. Trend and geographic analysis of the prevalence of dengue in Taiwan, 2010-2015. Int J Infect Dis [Internet]. 2017;54:43-9. Available from: http://dx.doi.org/10.1016/j.ijid.2016.11.008

27. Suryani ET. The Overview of Dengue Hemorrhagic Fever Cases in Blitar City from 2015 to 2017. J Berk Epidemiol. 2018;6:260-7.

28. Sandra T, Sofro MA, Suhartono S, Martini M, Hadisaputro S. Faktor Yang Berpengaruh Terhadap Kejadian Demam Berdarah Dengue Pada Anak Usia 6-12 
Tahun. J Epidemiol Kesehat Komunitas. 2019;4(1):1-10.

29. Triwahyuni T, Husna I, Andesti M. Hubungan Curah Hujan dengan Kasus Demam Berdarah Dengue di Bandar Lampung 2016-2018. J Ilmu Kesehat. 2020;1(3):184-9.

30. Feeley KJ, Stroud JT. Where on Earth are the "tropics"? Front Biogeogr. 2018;10(12):1-7.

31. Tarmana D. Potensi Peluang Demam Berdarah Dengue (Dbd) Berdasarkan Proyeksi Perubahan Iklim (Study Kasus : Dki Jakarta). Indones J Infect Dis. 2017;1(2):14.

32. Angelina CR, Windraswara R. Factors Related with Dengue Hemorrhagic Fever Incidence in 2008-2017. Unnes J Public Heal. 2019;8(1):64-72.

33. Yuliawati S, Kharisma D fajar, Martini M, Saraswati, Lintang Dian Hestiningsih R, Purwantisari S. Populasi Vektor Demam Berdarah Dengue Di Daerah Rural Kota Semarang: Crossectional Survey Bionomik Aedes Sp. Visikes, J Kesehat Masy [Internet]. 2020;19(2):459-65. Available from: http://publikasi.dinus.ac.id/index. php/visikes/article/view/3659

34. Kaeng LW, Warouw F, Sumampouw OJ. Perilaku Pencegahan dan Kepadatan Hunian dengan Kejadian Demam Berdarah Dengue. Junral Public Heal Community Med. 2020;1(3):3-8.

35. Hidayat, Nasriah. faktor yang berhubungan dengan kejadian DBD di Pulau Balang Lompo Kabupaten Pangkep. J Sulolipu Media Komun Sivitas Akad dan Masy. 2017;17(II):73-81.

36. Rosdawati. Hubungan Perilaku Kesehatan dengan Kejadian Demam Berdarah Dengue (DBD) di Wilayah Kerja Puskesmas Ma . Kumpeh Kecamatan Kumpeh Ulu Kabupaten Muaro Jambi. J Akad Baiturrahim Jambi. 2021;10(1):250-7.

37. WHO. Dengue and severe dengue fact sheet: World Health Organization [Internet]. 2016. Available from: http://www.who.int/mediacentre/factsheets/fs117/en/.

38. Sukayuni N putu eka, Prihandhani IS, Artana IW. Peran Jumantik Pada Kejadian Demam Berdarah Dengue: Studi Potong Lintang di UPTD Puskesmas Kuta Selatan. J Ilmu Keperawatan Komunitas. 2021;4(1):1-5. 